\title{
Strategy implementation in South African public entities between 2006 and 2016: Does leadership impact on performance during strategy implementation?
}

\begin{tabular}{|c|c|}
\hline \multicolumn{2}{|c|}{$\begin{array}{l}\text { Author: } \\
\text { Moses M. Gasela }{ }^{1}\end{array}$} \\
\hline \multicolumn{2}{|c|}{$\begin{array}{l}\text { Affiliation: } \\
{ }^{1} \text { Department of Business } \\
\text { Management, Economics and } \\
\text { Management, University of } \\
\text { the Free State, Bloemfontein, } \\
\text { South Africa }\end{array}$} \\
\hline \multicolumn{2}{|c|}{$\begin{array}{l}\text { Corresponding author: } \\
\text { Moses Gasela, } \\
\text { 2013088543@ufs4life.ac.za }\end{array}$} \\
\hline \multicolumn{2}{|c|}{$\begin{array}{l}\text { Dates: } \\
\text { Received: } 18 \text { Apr. } 2021 \\
\text { Accepted: } 06 \text { Oct. } 2021 \\
\text { Published: } 30 \text { Nov. } 2021\end{array}$} \\
\hline \multicolumn{2}{|c|}{$\begin{array}{l}\text { How to cite this article: } \\
\text { Gasela, M.M., 2021, 'Strategy } \\
\text { implementation in South } \\
\text { African public entities } \\
\text { between } 2006 \text { and 2016: } \\
\text { Does leadership impact on } \\
\text { performance during strategy } \\
\text { implementation?', Africa's } \\
\text { Public Service Delivery and } \\
\text { Performance Review 9(1), } \\
\text { a562. https://doi.org/ } \\
\text { 10.4102/apsdpr.v9i1.562 }\end{array}$} \\
\hline \multicolumn{2}{|c|}{$\begin{array}{l}\text { Copyright: } \\
\text { (C) 2021. The Authors } \\
\text { Licensee: AOSIS. This } \\
\text { is licensed under the } \\
\text { Creative Commons } \\
\text { Attribution License. }\end{array}$} \\
\hline \multicolumn{2}{|l|}{ Read online: } \\
\hline 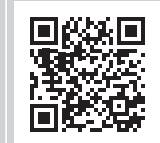 & $\begin{array}{l}\text { Scan this QR } \\
\text { code with your } \\
\text { smart phone or } \\
\text { mobile device } \\
\text { to read online. }\end{array}$ \\
\hline
\end{tabular}

Background: Those in leadership must always envision endless possibilities even in the event of what appear to be insurmountable problems. Leadership exists to solve problems in any given context. Leadership is a determinant of value creation and sustainable competitive advantage through superior organisational performance in any organisation. Yet, pervasive leadership challenges are prevalent in the South African public entities, and not a lot of research has been done in this area. Hence, this research was an attempt to determine the influence of leadership on organisational performance during strategy implementation in the Northern Cape based public entities.

Aim: To empirically investigate the relationship between leadership and organisational performance during strategy implementation in the Northern Cape provincial public entities in South Africa.

Setting: Public entities in the Northern Cape province with regards to relationships amongst financial and human resources, poor organisational culture, leadership, organisational performance, as well as service delivery.

Method: A survey design and mixed methods were applied in this study. A survey questionnaire was used to collect quantitative data from a simple random sample of 38 executives of the public entities and government departments in the Northern Cape province. The response rate was $78 \%$. The $t$-test, correlational analysis, multiple regression analysis were performed. These were complemented by content analysis of government's strategic documents.

Results: It was found that unqualified leadership and insufficient financial and human resources affect strategy implementations and organisational performance negatively. Most entities have problems with leadership capacity, which creates strategy implementation challenges. Weak Boards in some entities translate into weak leadership because there is no direction in the entities.

Conclusion: Unqualified leadership affect organisational performance negatively. This implies that the public sector entities might fail to fulfil their mandate to serve the public. Recommendations are made to minimise the challenges of leadership in the South African public entities to increase organisational performance. When appointing Board members, the quality of the members in terms of qualifications should be considered. Board members, apart from having competence and requisite skills to execute the mandate in the entity, should also be visionary and dedicated to the province. They should provide ethical leadership and corporate governance both at the strategic and governance level. Ethical and honest leadership which is not tainted by corruption (real or perceived) is of critical importance in any organisation and setting.

Keywords: leadership; organisational performance; strategy implementation; public entities; South Africa.

\section{Introduction and background}

This research study empirically determined the relationship between leadership and organisational performance during strategy implementation in the Northern Cape provincial public entities in South Africa. Although the poverty rate and unemployment rate seemingly decreased between 2006 and 2016, the Northern Cape provincial economy made the smallest contribution to national gross domestic product (GDP) in 2016. The GDP growth rate of the province was less than that of 
South Africa - for example, it was $-2.7 \%$ in 2016 , the negative growth rate being attributed to contraction in agriculture, mining, electricity and transport industries. There was an increase in the unemployment rate in the province from $22.6 \%$ in 2016 to $29.4 \%$ in 2019 ; with the largest expanded unemployment rate of $45.1 \%$ being recorded in the first quarter of 2020 (Republic of South Africa, STATS SA, 2nd quarter bulletin 2020).

Nhema (2015:247) as well as Suleiman, Hamad and Sulaiman (2017) defined public entities as organisations, which:

$[A]$ re incorporated under a specific legislation, that are controlled by the state, through a majority or $100 \%$ shareholding, in order to achieve certain service delivery strategic objectives of the state in the key sectors of the economy. (p. 161)

Schedule 3 public entities that were studied in this study make a significant contribution to the economy of the province and serve as an important vehicle for the realisation of the government infrastructure expansion programmes and other service delivery programmes. For instance, because of the Northern Cape Tourism Authority's marketing campaigns, international tourism in the Northern Cape province contributed R1.1 billion to the provincial economy during the financial year (FY) 2016/17 (South Africa, Northern Cape Tourism Authority Annual Report 2017:12).

While delivering the national budget speech of 2016, the Minister of Finance reflected on the importance and unique role of the South African public entities in terms of South African government's service delivery. In addition, he said that South African public entities boosts South Africa's economic growth and development with an 'asset base of more than R1 trillion, which is about 27 per cent of GDP' (Republic of South Africa, National Treasury Budget Speech 2016:18). While comparing this amount to that of R1.67 trillion of the South African budget for the FY 2018/19, it is about $62 \%$ of the country's budget.

Nationally, even though public entities are very important, considering the role they play economically, they are experiencing serious performance and service delivery problems and challenges. For example, during the FY 2015/16, the Northern Cape Economic Development, Trade and Investment Promotion Agency (NCEDA) experienced problems with all its performance indicators of service delivery with them being not consistent with the approved Annual Performance Plan (APP) and strategic plan. This implies that the public entity did not achieve its strategic objectives and service delivery targets to the satisfaction of the public entity's auditors (South Africa, NCEDA annual report, 2015:36). McGregor museum lacked financial resources to enable the public entity to achieve some of its mandated and strategic objectives. Furthermore, the public entity had a deficit in the 2015 statement of financial performance (South Africa, McGregor Museum Annual Report 2016:35). Kalahari Kid Corporation received a qualified audit opinion on its financial statements and service delivery performance report (South Africa, Kalahari Kid
Corporation Annual Report 2016:42). Some public entities have even been provided with financial bailouts (Tshandu 2018:2). It could be argued that when an organisation is bailed out through a financial rescue package or when embarking on a turnaround strategy, those are explicit indicators that the organisation is in distress and not well. The root causes of the problem can at times be traced and attributed to inappropriate and inadequate alignment of its strategies at both corporate and business levels (Gasela 2021).

Drucker (1988:68) stated that, 'leadership does matter with its essence on performance'. According to Shaari et al. (2014:246), Ali and Hadi (2012:265) as well as White (2004:620), leadership is key when it comes to implementing organisations' plans to ensure success of the strategic objectives such as profitability, growth and future positioning. Hendriks and Reddy (2020:26) argued that leaders who adopt a transformational and transactional leadership style can influence strategy implementation positively. During the 2016 national budget speech, Gordhan (in Paton 2018:1) was of the view that South African public entities require effective leadership to ensure effective strategy implementation and to improve performance. Also, others such as Kuye and Ajam (2012:48) and the Auditor-General of South Africa (AGSA) Public Finance Management Act (PFMA) general report (2013:1) found that there is a lack of leadership in South African public entities, which results in ineffective strategy implementation and poor performance. While scrutinising the websites and directors' reports in the annual reports of the public entities, it was found that some public entities have poor performance outcomes and are busy implementing turnaround strategies.

Generally, public entities are meant to attain the government's developmental objectives and in doing so, contend with unprecedented demands from the society along with complex environments. The failure of implementing corporate and business level strategies by South African public sector organisations, and their non-alignment are negatively influencing the public entities' organisational performance (Schniederjans \& Cao 2009; Seifzadeh 2013). This influence is moderated by corporate controls, leadership, size of head office/its capacity, strategy culture-fit, and diversification. The moderating variables also affect the implementation and alignment of the strategies, as well as the organisational performance (Farahmand 2010:12; Harinarain, Bornman \& Botha 2013; Shaari et al. 2014:246). The performance and service delivery of the current public sector entities in the Northern Cape province are not good for, amongst other problems and challenges, there is lack of effective leadership. However, the impact of ineffective leadership on organisational performance during strategy implementation in South African public entities in the Northern Cape province is not known. This study therefore focused on the public sector entities in the Northern Cape province as an attempt to identify the impact of leadership on organisational performance during strategy implementation in South African public entities in the Northern Cape province, and 
then recommend organisation performance enhancement mechanisms for the public entities.

After the introduction and background, this article presents literature review and theoretical framework (section 2), research methodology (section 3), findings and managerial implications (section 4) and limitations of the study (section 5) are presented. Section 6 concludes the study.

\section{Literature review and theoretical framework}

The inability of implementing the strategies at the corporate and business levels by public sector organisations is negatively influencing organisational performance in South African public entities. This influence is moderated by, amongst others, leadership, which also affects the implementation and alignment of the strategies, as well as the organisational performance.

\section{Leadership}

According to Delić, Kozarević and Alić (2017:65) and Barnes and Spangenburg (2018:49), there is no unanimous definition of leadership as it is a multi-faceted construct that is contextual by nature. The following are some of the leadership definitions, which describe its meaning according to certain perspectives:

- 'Leadership is the process of influencing others to understand and agree about what needs to be done and how to do it, and the process of facilitating individual and collective efforts to accomplish shared objectives' (Yukl 2010:26).

- 'Leadership is the process of enhancing and encouraging the self-esteem of employees to achieve organisational task and goals' (Muhammad, Su \& Saqib 2017:144).

- 'Leadership is an influence which motivates others to maximise the efforts towards achieving their organisational goals' (Zuned 2017:10).

- 'Leadership is a process of societal control for leader to pursue the controlled involvement with subordinate in order to attain organisational objectives and goals' (Mohiuddin 2017:18).

- 'Leadership is the mobilisation and influencing of people to work towards a common goal through the building of interpersonal relationships and the breaking of tradition to achieve the organisation's objectives, despite risk and uncertainty' (Van Schalkwyk, Davis \& Pellissier 2013:227).

From the abovementioned definitions of leadership, certain components pertaining to the meaning of leadership are deconstructed as follows:

- Leader: The main element of the definitions is that there is a person or group of persons who lead.

- Follower: This is another important variable of the definitions. The term follower is used to describe 'a person who acknowledges the focal leader as...primary source of guidance about work, regardless of how much formal authority the leader actually has over the person' (Yukl 2010:198). These are the people who don't directly write reports, such as co-workers, team members, partners, outsiders. A follower is therefore a broad construct that goes beyond direct subordinates of a leader.

- Process: It is evident in the definitions that in each leadership process, there is a specific context to achieve certain goals and objectives.

- Influence: This is another key word that forms part of the aforesaid definitions. According to Yukl (2010:198), 'influence is the essence of leadership that is necessary to influence people to carry out requests, support the proposals and implement decisions' using different sources of 'power'.

Power, in the view of Wang, Chen and Yu (2017:1199), is about '...the ability that one party must change or control the opinions, objectives, attitudes, behaviours, needs, and values of another party'. French and Raven (1959, cited in Wang et al. 2017:1199) provided the following as the important sources of power at the disposal of a leader to influence people:

- Coercive power is a kind of influence process whereby the leader is perceived to give punishment to the followers for mistakes and failures.

- Reward power is practiced in such a way that the followers sees the leader as someone who would pay them for the preferred behaviour.

- Legitimate power is about followers' perceptions of their leader as having authority to give direction and control of their behaviours.

- Expert power means that the followers believe that the leader has experience, knowledge and expertise in a specific area within the influence context.

- Referent power is of the type whereby the followers have a desire to identify with their leader because of their personal admiration and genuine liking of the leader.

Referring to the abovementioned de-constructed constructs of the definitions of leadership, it is evident that all those constituent elements should exist for the leadership process to take place. Winston and Patterson (2006) referred to leadership as a situation whereby:

$[A]$ leader is one or more people who select, equip, train, and influence one or more follower(s) who have diverse gifts, abilities, and skills and focus the follower(s) to the organisation's mission and objectives causing the follower(s) to willingly and enthusiastically expend spiritual, emotional, and physical energy in a concerted coordinated effort to achieve the organisational mission and objectives. (p. 7)

Although this definition also covers the common themes that were included in previous definitions covered thus far, it introduces an interesting human resources and psychological perspectives as it incorporates constructs such as 'selection', 'equipment', 'training', 'gifts', 'ability', 'emotion', 'diversity', and so on. 
From a slightly different angle compared to all the previous definitions, Jain and Jain (2013:43) introduced new aspects to the definition of leadership, through an inclusion of the specific leadership attributes such as 'character and values' that are used by the leader during the influence process. By its emphasis on leader attributes such as 'character and values', Jain and Jain's (2013:43) definition seems to be having its theoretical underpinning in the trait leadership theory. According to Khan (2013:830), the trait leadership theory is premised on the view that a leader influences others by possessing certain unique characteristics and qualities.

The South Africa's PFMA (1999:1) and AGSA PFMA general reports (2015) inform us that leadership of a South African public entity includes some of the following:

- Board of Directors, which is referred to as the Accounting Authority.

- Heads of Department who are referred to as the Accounting Officers.

- Chief Executive Officer (CEO).

- Executive Directors such as Chief Financial Officer (CFO) and other programme managers responsible for certain programmes/divisions in the public entities.

For this study, 'leadership' meant one or more people such as the board of directors, CEOs, CFOs who are perceived to use different sources of power to influence their followers and others in the context of South African public entities for the purposes of implementing a strategy that is intended to achieve the organisation's mission and objectives.

\section{Strategy implementation}

Thompson et al. (2010:41) defines strategy implementation as a 'conversion of strategic plans into actions and results'. There is a widely held view that public sector organisations in South Africa have excellent and detailed strategies and plans, but fail to implement them effectively. A scan of recent and reliable sources suggests that there is a consensus amongst management scholars and authors such as Harinarain et al. (2013), Shaari et al. (2014:246) and Farahmand (2010:12) regarding the critical importance of strategy implementation in general that constructs such as leadership, organisational culture, and corporate controls are some of the strategy implementation enablers that influence the corporate and business strategies alignment and organisational performance.

\section{Organisational performance}

In the opinion of Ramaseshan, Ishak and Rabbanee (2013:465), organisational performance is an outcome of strategy implementation to achieve the strategic goals. According to Serfontein and Hough (2011:6) and Alshamari and Ihrig (2017:129), there seems to be wide acceptance amongst management authors that organisational performance is a dependent variable in an organisation. It seems that there are different performance expectations by stakeholders for different organisations, especially between public entities and pure profit orientated private sector companies. The implication of the aforesaid unique nature of performance expectation of the public entities creates an inevitable tension between developmental mandated performance considerations for the country that are not always commercially viable. This is because these entities are expected to meet commercial considerations, such as to be profitable whilst at the same time they are expected to undertake national projects that are good for the country and national economy, but not necessarily commercially attractive. Based on these perspectives, it could be suggested that performance expectations for South African public entities are unique compared to traditional privately owned and public service organisations.

In the opinion of Bhamornsathit and Katawandee (2016:56), internal and external stakeholders of organisations use different performance measures to evaluate organisational performance. Drucker (1974) believed that an organisation should aim to select performance matrices that measure the overall organisational performance. Financial performance measures, annual audit opinions and non-financial service delivery matrices are the relevant performance measures for a study of South African public entities. These three performance measures have relevance to this study, because the legislation (i.e. PFMA [1999], NCEDA Act no. 4 of 2008, Northern Cape Gambling Act no.3 of 2008, etc.) requires that all South African public entities produce various financial and service delivery reports to indicate their performance to the public for the purposes of compliance and accountability.

\section{Leadership, strategy implementation and performance}

It appears that there is a consensus on the role of leadership during strategy implementation amongst researchers such as Delić et al. (2017:65), and O'Reilly et al. (2010:104). According to O'Reilly et al. (2010:104), Serfontein and Hough (2011:393), Van Schalkwyk et al. (2013:227), Gyllstrom et al. (2015:313), Prasad et al. (2018:6), and Delić et al. (2017:65), the leadership of an organisation enables strategy implementation with an influence on organisational performance. Frantz and Jain (2017:746) found that the leadership behaviour in an organisation influences the organisational culture, which in turn influences organisational performance. In a study of Zanzibar public entities, Suleiman et al. (2017:159) found that ineffective boards and CEOs in public entities result in poor organisational performance. Vermeeren et al. (2014:174), Samanta and Lamprakis (2018:173), Rasoolimanesh et al. (2015:156), Yahaya and Ebrahim (2016:190) as well as Oyewobi et al. (2016:2340) found that leadership, which includes different leadership styles and decision-making styles, has an influence on organisational performance during strategy implementation. Hasan and Khajeh (2018:6) found that 'democratic leadership, transformational leadership and autocratic leadership style have a positive relationship with the organizational performance'. 


\section{Strategy implementation}

In the view of Hough et al. (2008:259) and Higgins (2005:6), the eight ' $\mathrm{S}$ ' of a successful strategy implementation model has eight organisational factors which must be aligned to each other to ensure a successful implementation of the strategy and a positive influence on organisational performance. These are: strategy and purpose, systems and processes, shared values (organisational culture), leadership style, resources, staff, skills and strategic performance. According to Higgins (2005), the misalignment of these factors results in poor organisational performance.

According to Van der Merwe and Nienaber (2015:53), Grabovica and Pilav-Velić (2012:218), Kotzé and Venter (2010:413) as well as Volberda et al. (2011:424), poor leadership in an organisation creates challenges to strategy implementation. Kotzé and Venter's (2010:413) public sector study produced an alarming outcome of the research that participants scored the poorest in terms of the implementation of plans, when compared to similar participants from organisations in the private sector. Kotzé and Venter (2010:413) came up with a different contention by suggesting that leaders should possess a mix of different leadership styles in order to implement a strategy effectively. The views of some of the leadership authors, such as Maseti and Gumede (2011) and Kunnatt (2016) appear to be in line with the contingency leadership theory. According to Khan (2013), the core principle of contingency leadership theory is that each situation is different and thus, no one approach can fit all situations; instead, leadership complexities themselves must cater for the differences in situations and adapt accordingly.

Jordão and Novas (2013:105), Basheka (2014:653), Grabovica and Pilav-Velić (2012:218), Monauni and Feigl (2017:1), Sull, Homkes and Sull (2015:7) as well as Gyllstrom et al. (2015:313) argued that 'a breakdown in communication between key role players responsible for strategy implementation ... a lack of information are the key challenges in strategy implementation'. and often instrumental in ineffective strategy implementation. In their investigations of various organisations, Van der Merwe and Nienaber (2015:53) and MacQueen and Bradford (2017:321) found that lack of communication and the resultant failure to understand the strategy targets well by stakeholders in organisations lead to implementation challenges. Prasad et al. (2018:6) argued that lack of resources is a major challenge of strategy implementation. Pella et al. (2013:183), and Reitsma and Hilletofth (2018:285) found that a lack of financial and technical resources is a serious hindering factor that can impact negatively on effective strategy implementation.

Zheng, Young and Mclean (2010:765) stated that the accrual of unique resources and capabilities to the organisation resulting from pursuance of certain strategies at the corporate level has theoretical underpinnings in the resource-based theory. In terms of the resourced-based view, an organisation sources its competitive advantage on 'tangible and intangible assets that are valuable, rare, imperfectly imitable and sustainable' (Gaya, Struwig \& Smith 2013:2053; Kogo \& Kimencu 2018:132; Zheng et al. 2010:765). In the view of Farahmand (2010:12), an organisation implements its strategy with success when it selects appropriate corporate controls that match the chosen strategy. Because of the significance of corporate controls during strategy implementation, it is clear that, responsible management would put in place suitable control systems to ensure successful implementation. Van der Merwe and Nienaber (2015), and Patten (2015:288) indicated that leadership problems in an organisation are key challenges to strategy implementation. According to Van der Merwe and Nienaber (2015:53), Grabovica and Pilav-Velić (2012:218), Patten (2015:288) as well as Volberda et al. (2011:424), poor leadership in an organisation creates challenges to strategy implementation.

This study is underpinned by the agency theory; and according to this theory (Martin \& Sayrak 2003):

$[P]$ ursuance of certain corporate level strategies of organisations can be explained as an attempt by the management of the parent department to advance their personal interests such as power, good salaries, influence and goals at the expense of shareholders. (p. 40)

\section{Research design and methodology}

The survey design (Leedy \& Ormord 2013) and a mixed methods approach were used in this study. Saunders et al. (2009) stated that this design helps a researcher to obtain massive data from the target population quickly and economically. The targeted population was made up of the 40 public entities' executives and the six executives from the three controlling provincial government departments in the Northern Cape province. These three provincial government departments directly control the eight Northern Cape province's public entities through the public entities' boards of directors. The government executives are in charge of business level strategy formulation and implementation, which must be aligned to the corporate strategies. A simple random sample of 32 of the 40 public entities' executives $(80 \%)$ and the six executives from the three controlling provincial government departments, making a total sample of 38 respondents $(38 / 46=82.6 \%)$, was used to collect the quantitative data.

A self-administered questionnaire was emailed to the respondents to collect data, using the 5-point Likert scale. The $t$-test, correlational analysis and multiple regression were used to determine the relationships between variables. The Statistical Package for Social Science Version 27 (SPSS) was used. Content analysis of the government strategic documents was also done.

\section{Reliability and validity, and ethical considerations}

The study's validity and reliability were ensured by piloting the questionnaire, and applying triangulation and the 
divergent mixed methods approach. Approvals to undertake the study were obtained from the Faculty of Economic and Management Sciences Ethics Committee of University of Free State for ethical clearance (Ref. no.: UFS-HSD2018/0003); and the public entities' CEOs. Respondents also signed a written informed consent form for voluntary participation. It should be noted that public entities' strategic documents and annual reports are publicly available on their respective websites. Content analysis of these documents complemented the analysis of the primary data.

\section{Findings and managerial implications}

This part consists of two parts. Part 1 presents results of descriptive analysis, whereas, part 2 presents the results of inferential analysis.

\section{Descriptive analysis}

Most of the respondents were aged between 35 and 44 years (50\%), and were males (73.3\%). This might indicate that there is still gender discrimination in South Africa's workplace. The majority of respondents $(93.34 \%$ ) had a management experience of less than 20 years; and most of them had either a degree or a diploma in management science. Hence, it was assumed that the participants had the needed experience and knowledge to be able to execute their functions properly and to provide valid and reliable information on the issues that were being investigated in this study.

Table 1 provides mean scores, standard deviation (SD), median and mode for the role of leadership during strategy implementation in South African public entities. On the Likert Scale, the mean scores range between 1.379 (almost 'strongly agree') to 3.3 (almost 'neutral'). The mean score is between 2 (agree) and 3 (neutral) for most of the statements. Statement 1 (i.e. There is less turnover of leadership in the public entity, resulting in successful strategy implementation and improved organisational performance) has the maximum mean score of 3.3 ( $\mathrm{SD}=1.088$ ), which is almost 3 (neutral) with a median of 4 and a mode of 4 ; and statement 7 (i.e. Effective leadership is one of the mechanisms that can result in the improvement of the alignment gaps between the corporate and business level strategies of the public entity) has the minimum mean score of $1.379(\mathrm{SD}=0.494)$, which is between 1 (Strongly agree) and 2 (Agree).

According to the $t$-test, the respondents disagreed with only statement 1 (i.e. There is less turnover of leadership in the public entity, resulting in successful strategy implementation and improved organisational performance). They were neutral/undecisive for statements 3,4 and 5, that is, 'The public entity met its service delivery strategic objectives in the previous FY because of the effectiveness its leadership', 'The public entity met its financial strategic objectives during the previous FY because of the effectiveness its leadership' and 'The absence of a permanent CEO or CFO or Board resulted in the public entity not meeting its performance objectives during the previous reporting period'. They agreed with statements 2, 6 and 7, that is 'Leadership at key levels of the entity has requisite competencies to ensure successful strategy implementation and improved performance', 'Leadership in the entity has a positive influence on the alignment between its corporate and business level strategies with organisational performance' and 'Effective leadership is one of the mechanisms that can result in the improvement of the alignment gaps between the corporate and business level strategies of the public entity'. In general, the respondents were not sure about the role of leadership during strategy implementation.

TABLE 1: Role of leadership during strategy implementation.

\begin{tabular}{|c|c|c|c|c|c|c|c|c|c|}
\hline Number & Statement & $\begin{array}{c}\text { Number of } \\
\text { observations }\end{array}$ & Mean score & $\begin{array}{l}\text { Standard } \\
\text { deviation }\end{array}$ & Median & Mode & $t$ & Probability & Conclusion \\
\hline 1. & $\begin{array}{l}\text { There is less turnover of leadership in the } \\
\text { public entity, resulting in successful strategy } \\
\text { implementation and improved organisational } \\
\text { performance. }\end{array}$ & 30 & 3.3 & 1.088 & 4 & 4 & 1.511 & 0.071 & Disagreed \\
\hline 2. & $\begin{array}{l}\text { Leadership at key levels of the entity has } \\
\text { requisite competencies to ensure successful } \\
\text { strategy implementation and improved } \\
\text { performance. }\end{array}$ & 30 & 2.4 & 0.855 & 2 & 2 & -3.844 & 0.000 & Agreed \\
\hline 3. & $\begin{array}{l}\text { The public entity met its service delivery } \\
\text { strategic objectives in the previous financial } \\
\text { year because of the effectiveness of its } \\
\text { leadership. }\end{array}$ & 29 & 2.931 & 1.193 & 4 & 4 & -0.311 & 0.379 & Neutral \\
\hline 4. & $\begin{array}{l}\text { The public entity met its financial strategic } \\
\text { objectives in the previous financial year } \\
\text { because of the effectiveness of its leadership. }\end{array}$ & 29 & 3 & 1.134 & 4 & 4 & 0.000 & 0.500 & Neutral \\
\hline 5. & $\begin{array}{l}\text { The absence of a permanent CEO or CFO or } \\
\text { Board resulted in the public entity not } \\
\text { meeting its performance objectives during } \\
\text { the previous reporting period. }\end{array}$ & 30 & 3.133 & 1.167 & 4 & 4 & 0.626 & 0.268 & Neutral \\
\hline 6. & $\begin{array}{l}\text { Leadership in the entity has a positive } \\
\text { influence on the alignment between its } \\
\text { corporate and business level strategies with } \\
\text { organisational performance. }\end{array}$ & 30 & 2.4 & 1.037 & 2 & 2 & -3.168 & 0.002 & Agreed \\
\hline 7. & $\begin{array}{l}\text { Effective leadership is one of the mechanisms } \\
\text { that can result in the improvement of the } \\
\text { alignment gaps between the corporate and } \\
\text { business level strategies of the public entity. }\end{array}$ & 30 & 1.533 & .507 & 2 & 2 & -15.832 & 0.000 & Agreed \\
\hline
\end{tabular}

CEO, Chief Executive Officer; CFO, Chief Financial Officer. 
TABLE 2: Correlational matrix.

\begin{tabular}{llcccc}
\hline Variable & Values & $\begin{array}{c}\text { Strategy } \\
\text { alignment }\end{array}$ & $\begin{array}{c}\text { Strategy } \\
\text { implementation }\end{array}$ & Leadership & $\begin{array}{c}\text { Organisational } \\
\text { performance }\end{array}$ \\
\hline Strategy & $r$ & 0.133 & 1.000 & - & - \\
implementation & $P$-value & 0.509 & - & - & - \\
& Obs. & 27 & 29 & - & - \\
Leadership & $r$ & 0.028 & $\mathbf{0 . 4 5 1 * *}$ & 1.000 & - \\
& $P$-value & 0.887 & $\mathbf{0 . 0 1 6}$ & - & - \\
& Obs. & 28 & $\mathbf{2 8}$ & 29 & - \\
Organisational & $r$ & 0.003 & 0.116 & $\mathbf{0 . 3 6 3 *}$ & 1.000 \\
performance & $P$-value & 0.988 & 0.549 & $\mathbf{0 . 0 5 3}$ & - \\
& Obs. & 28 & 29 & $\mathbf{2 9}$ & 30 \\
\hline
\end{tabular}

$r$, correlation coefficient; Obs., number of observations.

*, significant at the $10 \%$ level; **, significant at the $5 \%$ level; ***, significant at the $1 \%$ level.

TABLE 3a: Regression model.

\begin{tabular}{lccc}
\hline Source & Sum of squares & $\begin{array}{c}\text { Degrees of } \\
\text { freedom }\end{array}$ & Mean square \\
\hline Model & 262.978 & 2 & 131.489 \\
Residual & 11.800 & 26 & 0.454 \\
\hline Total & $\mathbf{2 7 4 . 7 7 8}$ & $\mathbf{2 8}$ & $\mathbf{9 . 8 1 3}$ \\
\hline
\end{tabular}

Probability $>F=0.000 ;$ Number of observations $=28 ; F(2,26)=289.73 ; R$-square $=0.957$ Adjusted R-square $=0.954$

TABLE 3b: Regression model.

\begin{tabular}{lcccccc}
\hline Variable & Coefficient & $\begin{array}{c}\text { Standard } \\
\text { error }\end{array}$ & $T$ & Probability & \multicolumn{2}{c}{$\begin{array}{c}95 \% \text { confidence } \\
\text { interval }\end{array}$} \\
\cline { 3 - 7 } & & & & Lower & Upper \\
\hline Leadership & 0.623 & 0.211 & 2.95 & 0.007 & 0.188 & 1.058 \\
\hline
\end{tabular}

\section{Inferential statistical analysis}

\section{Correlational analysis}

Table 2 shows the correlations between the key constructs indicating that leadership is positively correlated with strategy implementation $(r=0.451$, prob. $=0.016<0.05)$ and organisational performance $(r=0.363$, prob. $=0.053<0.1)$.

\section{Regression analysis}

The results in Table 3 provide the regression model for organisational performance. The model is highly significant (prob. $=0.000<0.01$ ) at the $1 \%$ level. The role of leadership during strategy implementation $(t=2.95$, prob. $=0.007<0.01)$ is also significant at the $1 \%$ level; it affects the organisational performance positively. The Adjusted R-square is 0.954, which means that the model explains $95.4 \%$ of the total variation of organisational performance. This means leadership explain the variation of organisational performance of $95.4 \%$.

The issues of leadership in South African public entities revolve around funding constraints that limit the entities' performance. South Africa needs to change the funding process in general; the funding as per population and size of population does not work for the Northern Cape as it is vast. The Northern Cape Province takes up approximately 30.5\% of South Africa's land area, making it the largest province in the country. Even though the province is geographically vast, it has the least population compared to the other eight provinces, of approximately over 1.2 million people, which translates to about $2 \%$ of the national population total. Yet, the national equitable share formula to allocate national budget across all nine provinces uses the population as a driver and determinant.

The national equitable share formula does not take into account the qualitative factors that are unique to the province such as geographical dispersion, rurality and so forth. This results into transport costs significantly increasing the costs of service delivery; that is, because of the vast geographical distances between the province's economic centres. It translates into lack of financial resources which should be available for strategy implementation. Financial resource allocation therefore causes strategy implementation challenges. In addition, there is lack of boards that are strong and have a vision to drive entities. Skill must also be considered, not only numbers when appointing board members.

About $66 \%$ of the respondents disagreed that there is less turnover of leadership in the public entity, resulting in a successful strategy implementation and improved organisational performance. Over $60 \%$ of the respondents agreed with statements: leadership at key levels of the entity has requisite competencies to ensure successful strategy implementation and improved performance; leadership in the entity has a positive influence on the alignment between its corporate and business level strategies with organisational performance, and that effective leadership is one of the mechanisms that can result in the improvement of the alignment gaps between the corporate and business level strategies of the public entity.

Leadership: There are issues with leadership, managerial leadership and the CEOs in the public entities. These issues basically revolve around the following:

- Boards are not effective for lack of requisite skills and ethical leadership, and for not being visionary. This implies that there are serious governance problems in such entities as all board decisions are defective in terms of the law as the boards are not properly constituted and do not form a quorum, which exposes the public entities to the risk of litigation for their resolutions.

- Having people in acting positions results in leadership ineffectiveness for the entity, which affects the entity's strategy alignment between the corporate and business levels, strategy implementation as well as organisational performance.

- Some board members are not functional as they lack the skill and are not attending meetings. Weak boards in some entities translate into weak leadership because there is no direction in the entities.

- Some entities do not exercise oversight responsibility to ensure effective development and implementation of internal control procedures that would make the entities able to produce accurate and complete reporting of annual financial statements and performance; and to ensure compliance with the applicable laws and regulations. For example, in terms of chapter 6, 
paragraph 51, section 1 (a) (iii) of the PFMA of 1999, and according to the National Treasury regulations, paragraph 9 , as amended in 2005, as a broad compliance requirement, all South African public entities are required to be costeffective in their operations such as procurement and provisioning as they are dealing with public funds.

- There is duplication of functions and a lack of the coordination function contributed to the negative organisational performance such as the negative audit outcomes and the non-achievement of the annual performance targets.

The finding that most public entities have problems with leadership capacity, which creates strategy implementation challenges supports those of Van der Merwe and Nienaber (2015:53), Patten (2015:288), Grabovica and Pilav-Velić (2012:218), Kotzé and Venter (2010:413) as well as Volberda et al. (2011:424). Board members must be well qualified; people who have a vision for the entity, dedicated, and can be ethical leaders. Appointing senior officials like CEO and CFO in acting capacity should be discouraged as this negatively affects the entity's strategy implementation and organisational performance.

The growth fund is supposed to be in NCEDA in terms of its implementation (not in the parent department) so that it can be used by the entity to drive the economic development of small and medium enterprises in the province. The high impact projects are currently in the provincial departments whereas the role of NCEDA is not limited to the Department of Economic Development and Tourism. The NCEDA should therefore stretch its wings across all departments of the province because it is an implementing agency of the province.

The implementation of strategies in public entities: Although the reflected business scope and purpose of the public entities' strategies are seemingly in line with the broad business scope and mandate as defined by the controlling departments' strategies, the entities do not implement them for several reasons, including, amongst others, lack of capacity (i.e. finance and human resources-HR), having no support from parent departments, no effective oversight and monitoring, no assessment of impact and feedback, working in silos, and no effective communication. In general, public entities set their performance targets according to the available resources and the limitations the entities have, and not strictly according to the corporate strategy, and therefore, alignment gaps occur between the two strategies. The two strategies, that is, corporate and business level strategies end up being not implemented. In general, the respondents were undecided with the statement that: the public entities implemented their strategies effectively during the previous reporting period.

The following issues also have an effect on the strategy implementation of the public entities:

- There is lack of staff and outsourcing is not easy either, because departments take long to process it. The qualifications of some key people (like those on the boards) in some of the entities are a concern. A major issue is the capacity at the level of the board.

- The financial resources and budget allocation are inadequate, which results in ineffective strategy implementation. Entities cannot reach a large number of people because of the limited financial resources because of the vastness of the province. Lack of funds is causing some entities to not comply with the Acts and PFMA. For example, the Liquor Board reports about inspections only in terms of number; they cannot give an analysis as per the Act. The gambling Board just puts targets of the number of inspections, not based on the type of license for a bottle store, tavern or a night club. Inspectors are based in Kimberley and the process of licensing is centralised; the issuing of licenses is not done at the region or district level which affects strategy implementation, alignment of the two-level strategies and organisational performance negatively.

- Working in silos and duplication of projects and programmes.

Most entities lack financial resources and human resources, which affects the implementation of their APPs negatively. This finding supports the findings of Prasad et al. (2018:6), Reitsma and Hilletofth (2018:285) and Pella et al. (2013:183). For example, the Northern Cape Tourism Authority's Board is supposed to consist of 12 people but currently, the entity has four active Board members. Without a quorum, the Board cannot make resolutions because according to the external audit committee, those resolutions could be challenged legally. Therefore, currently, the entity has a lot of policies that have not been approved.

\section{Limitations of the study}

In this study, the data were obtained only from the Northern Cape Province, which implies that the findings might not adequately apply to the whole of South Africa. A sample selected randomly does not promise to meet the characteristics of the population, hence, there is a possibility of drawing the wrong relationship between the variable as a result of the data collected randomly. Quantitative methods authenticity is often questionable because of the positivism philosophy. For instance, if the researcher believes that the truth is outside, it should be searched from outside. From this belief, the positivist researcher considers the data collected through a survey to be true, but he cannot verify the truthfulness of every single data point collected (Ayres 2017:90).

\section{Conclusions and recommendations Conclusions}

This article sought to determine the effect of leadership on organisational performance during strategy implication in the public entities. Unqualified leadership affect organisational performance negatively; the negative effect of unqualified leadership on organisational performance implies that the public entities might fail to fulfil their mandates to serve 
the public. One of the unique features of public sector entities, juxtaposed with the private sector, is that government is the major shareholder in public sector entities and the responsibility of appointing the Board members in the public sector entities lies with the government.

The major finding of this study is that unqualified leadership and lack of capacity, that is, financial and human resources, affect strategy implementations and organisational performance negatively. Most entities have problems with leadership capacity, which creates strategy implementation challenges. Weak Boards in some entities translate into weak leadership because there is no direction in the entities. Appointing senior officials like CEO and CFO in acting capacity is also a problem. Generally, entities have serious capacity (finance and human resources) challenges. Working in silos and duplication of projects and programmes, not only waste money, they also affect strategy implementation and organisational performance negatively.

\section{Recommendations}

The quality of Board members in terms of qualifications should be considered when appointing them. Board members, apart from having competence and requisite skills to execute the mandate in the entity, should also be visionary and dedicated to the province. They should also provide ethical leadership and corporate governance both at the strategic and governance level. If need be, they should be trained to understand the responsibility of being in the Board of Directors. They should be able to articulate, understand and analyse the governance issues affecting their respective entities.

The entities need guidelines of who should become a Board member, and what are the required qualities expected of him or her. Key stakeholders of the industry should be represented in the relevant Boards of the entities as non-executive directors to be able to provide industry specific advice and input on the strategic direction and matters affecting the relevant industry from the perspective of industry players. For instance, representatives of gambling or liquor licence holder associations should have a representation in the Boards of the Northern Cape Gambling Board and Northern Cape Liquor Board. The inclusion of the other key stakeholders from the industry will improve the quality of decisions and resolutions of the entities' Boards in the furtherance of service delivery and the execution of their mandates.

The Boards of the entities must always be appointed at the right time, before the term of the existing Board expires to ensure that there is continuity and there is no leadership vacuum at governance level. All entities should have a legal resource on their Boards. All Boards of the public entities should be given adequate inductions. During such inductions, the relevant Member of the Executive Council (MEC) who has appointed the Board should outline the parent department's expectations of the new Board. Furthermore, there should be regular meetings, for example, on a quarterly or biannually basis, between the Board and the MEC to appraise each other on the strategic direction and implementation in the entity at that highest level. Such meetings should discuss the high-level strategic issues regarding the achievement or non-achievement of the entities' strategic objectives, not routine operational issues.

Corporate governance should be adhered to by both the public entities and parent departments; and acting appointments of key executives in the entities such as CEO and CFO should be replaced by permanent appointments, and should be remunerated in accordance with the responsibilities attached to those key leadership positions to ensure stability and continuity in the entities.

\section{Acknowledgements}

The author acknowledges the following persons: Bongeka (my wife); our two daughters and son (Kwanda, Moses and Hlumela); Prof. Werner Vermeulen (my former PhD promoter); Prof. Victor Naidu at the Department of Planning, Monitoring and Evaluation (DPME); Ms Chantal Adams as well as all relevant editorial officials from the Journal for their support in different capacities. Finally the author acknowledges Adv. Justice Bekebeke (Director-General of the Northern Cape province) who is my Supervisor at work for the past 12 years for having supported me wholeheartedly in pursuing my research interests.

\section{Competing interests}

The author has declared that he has no financial or personal relationships that may have inappropriately influenced him in writing this manuscript.

\section{Author's contributions}

M.M.G. is the sole author for this manuscript.

\section{Funding information}

This research received no specific grant from any funding agency in the public, commercial or not-for-profit sectors.

\section{Data availability}

Data sharing is not applicable to this work as no new data were created or analysed for the research.

\section{Disclaimer}

The views and opinions expressed in this article are those of the author and do not necessarily reflect the official policy or position of any affiliated agency of the author.

\section{References}

Ali, M. \& Hadi, A., 2012, 'Surveying and identifying the factors affecting successful implementation of business strategies in companies of Fars province industrial town: Case study - Companies of food industries', International Journal of Business and Social Science 3(1), 265-272. https://doi.org/10.30845/ijbss

Alshamari, S. \& Ihrig, K., 2017, 'Organisational culture and organisational performance in the primary health care sector in Qatar: A proposed theoretical framework', Cross-cultural Management Journal 19(2), 129-138. 
Ayres, D., 2017, 'What use is research? Primary school teachers' experience of schoolbased practitioner research', Master's thesis, University of East London, viewed April 2019, from http://hdl.handle.net/10552/7340.

Barnes, L.L. \& Spangenburg, J.M., 2018, 'When leadership fails - A view from the lens of four employees', American Journal of Business Education 11(3), 49-54. https:// doi.org/10.19030/ajbe.v11i3.10188.

Basheka, B.C., 2014, 'What constraints a transformed public service in Uganda?', Journal of Public Administration 49(2), 653-671.

Bhamornsathit, S. \& Katawandee, P., 2016, 'An analysis of Thai listed hotels: Financia and operational performance', Journal of Business and Behavioural Sciences 28(2), 55-69.

Delić, A., Kozarevic, E. \& Alic, M., 2017, 'Impact of leadership style on bank profitability: Case study of a bank in Bosnia and Herzegovina', Journal of Contemporary Management Issues 22(2), 65-77.

Drucker, P.F., 1974, Management, tasks, responses, practices, Harper \& Row, New York, NY

Drucker, P.F., 1988, Two views of leadership. Leadership: More than a dash, McKinsey \& Company, New York, NY.

Farahmand, N.F., 2010, 'Strategic structure for organisational performance', International Journal of Management and Innovation 2(2), 9-23.

Frantz, T.L. \& Jain, A.K., 2017, 'Relating CEO leadership behavior and organisation culture in the Indian context', Leadership \& Organisation Development Journa 38(6), 746-764. https://doi.org/10.1108/LODJ-12-2015-0287

Gasela, M.M., 2021, 'The impact of strategy alignment on organisational performance in national public entities in the Northern Cape Province of South Africa', Africa's Public Service Delivery and Performance Review 9(1), a489. https://doi org/10.4102/apsdpr.v9i1.489

Gaya, H.I., Struwig, M. \& Smith, E.E., 2013, 'Creating a sustainable competitive advantage at a high performing firm in Kenya', African Journal of Business Management 7(21), 2049-2058.

Grabovica, E. \& Pilav-Velić, A., 2012, 'The biggest challenges of successful CRM implementation: Conceptual framework', Conference Proceedings: International Conference of the Faculty of Economics Sarajevo (ICES), University of Sarajevo, School of Economics and Business Bosnia and Herzegovina, of Sarajevo, School

Gyllstrom, E., Gearin, K., Frauendienst, R., Myhre, J., Larson, M. \& Riley, W., 2015 'Local health department factors associated with performance in the successful implementation of community-based strategies: A mixed-methods approach' American Journal of Public Health 105(2), 313-317. https://doi.org/10.2105/ AJPH.2014.302419

Harinarain, N., Bornman, C. \& Botha, M., 2013, 'Organisational culture of the South African construction industry', Acta Structilia 20(1), 22-43.

Hasan, E. \& Khajeh, A., 2018, 'Impact of leadership styles on organizational performance', Journal of Human Resources Management Research 2018(2018), Article ID 687849. https://doi.org/10.5171/2018.687849

Hendriks, C.J. \& Reddy, T., 2020, 'Leadership styles and strategy implementation in the National Department of Trade and Industry', Journal for New Generation Sciences 18(1), 16-30.

Higgins, J.M., 2005, 'The eight 'S's successful strategy execution', Journal of Change Management 5(1), 3-13.

Hough, J.,Thompson Jr, A.A., Strickland, A.J. \& Gamble, J.E., 2008, Crafting and executing strategy: Texts, Readings and cases, McGraw-Hill, Berkshire.

Jain, A.K. \& Jain, S., 2013, 'Understanding organisational culture and leadership: Enhance efficiency and productivity', Pranjana 16(2), 43-53.

Jordão, R.V.D. \& Novas, J.L.C., 2013, 'A study on the use of the balanced scorecard for strategy implementation in a large Brazilian mixed Economy Company', Journal of Technology Management and Innovation 8(3), 98-107. https://doi.org/10.4067/ S0718-27242013000400009

Khan, A., 2013, 'Approaches in leadership: Trait, situational and path-goal theory: A critical analysis', Pakistan Business Review 14(4), 830-842.

Kogo, P.K. \& Kimencu, L., 2018, 'Organisational capabilities and performance of insurance companies in Nairobi city county, Kenya', International Academic Journal of Human Resource and Business Administration 3(1), 126-149.

Kotzé, M. \& Venter, I., 2010, 'Perceptions of leadership effectiveness in the public sector: An empirical study', Journal of Public Administration 45(3), 413-435.

Kunnatt, J.T., 2016, '3D leadership - strategy linked leadership framework for managing teams', Economic, Management and Financial Markets 11(3), 30-55.

Kuye, J.O. \& Ajam, T., 2012, 'The South African developmental state debate: Leadership, governance and a dialogue in public sector finance', African Journal of Public Affairs 5(2), 48-67.

Leedy, P.D. \& Ormrod, J.E., 2013, The nature and tools of research, in practical research: Planning and design, Pearson Education, Boston, MA.

Macqueen, S. \& Bradford, B., 2017, 'Where did it all go wrong? Implementation failure and more in a field experiment of procedural justice policing', Journal of Experimental Criminology 13(3), 321-345. https://doi.org/10.1007/s11292-016Experim

Martin, J.D. \& Sayrak, A., 2003, 'Corporate diversification and shareholder value: a survey of recent literature', Journal of corporate finance 9, 37-57.

Maseti, Z. \& Gumede, N., 2011, 'Contemporary perspective on autocratic leadership' Journal of Public Administration 46(4), 1479-1487.

Muhammad, F.M., Su, Q. \& Saqib, A., 2017, 'Leadership styles and employee's motivation: Perspective from an emerging economy', The Journal of Developing Areas 51(4), 143-155. https://doi.org/10.1353/jda.2017.0093
Mohiuddin, Z.A., 2017, 'Influence of leadership style on employees performance: Evidence from literatures', Journal of Marketing and Management 8(1), 18-30.

Monauni, M., \& Feigl, A., 2017, 'Closing the strategy execution gap through business simulations', Topsim 1-6.

Nhema, A.G., 2015, 'Privatisation of public enterprises in developing countries: An overview', International Journal of Humanities and Social Science 5(9), 247-256.

O'Reilly, C.A., Caldwell, D.F., Chatman, J.A., Lapiz, M. \& Self, W., 2010, 'How leadership matters: The effects of leaders' alignment on strategy implementation', The Leadership Quarterly Journal 21, 104-113. https://doi.org/10.1016/j.leaqua.2009. 10.008

Oyewobi, L.O., Windapo, A.O., Rotimi, J.O.B. \& Jimoh. R.A., 2016, 'Relationship between competitive strategy and construction organisation performance: The
moderating effect of organisational characteristics', Management Decision 54(9), moderating effect of organisational characteristics', Man

Paton, C., 2018, 'Gordhan: Denel, SA express the most cash-strapped', Business Day, 16 August, p. 1.

Patten, L., 2015, 'The continued struggle with strategy execution', International Journal of Business Management and Economic Research 6(5), 288-295.

Pella, M., Sumarwan, U., Daryanto, A. \& Kirbrandoko, 2013, 'Factors affecting poor strategy implementation', GADJAH MADA International Journal of Business 15(2), 183-204. https://doi.org/10.22146/gamaijb.5702

Prasad, D.S., Pradhan, R.P., Gaurav, K., Chatterjee, P.P., Kaur, I., Dash, S. et al., 2018 'Analysing the critical success factors for implementation of sustainable supply chain management: An Indian case study', Decision (Calcutta) 45(1), 1-23.

Ramaseshan, B., Ishak, A. \& Rabbanee, F.K., 2013, 'The role of marketing managers' commitment and involvement in marketing strategy implementation', Journal of Strategic Marketing 21(6), 465-483.

Rasoolimanesh, S.M., Jaafar, M., Badarulzaman, N. \& Ramayah, T., 2015, 'Investigating a framework to facilitate the implementation of city development strategy using balance scorecard', Habitat International 46, 156-165. https://doi.org/10.1016/j. balance scorecard', Habito
habitatint.2014.12.003

Reitsma, E. \& Hilletofth, P., 2018, 'Critical success factors for ERP system implementation: A user perspective', European Business Review 30(3), 285-310. https://doi.org/10.1108/EBR-04-2017-0075

Republic of South Africa, 1999, Public Finance Management Act 1 of 1999, Government Printer, Pretoria.

Republic of South Africa, 2015, Northern Cape Economic Development, Trade and Investment Promotion Agency (NCEDA) annual report, Department of Economic Development and Tourism of the Northern Cape Provincial Administration, Government Printer, Pretoria.

Republic of South Africa, 2016, Kalahari Kid Corporation annual report annual report Department of Agriculture and Land Reform of the Northern Cape Provincial Administration, Government Printer, Pretoria.

Republic of South Africa, 2016, McGregor Museum annual report, Department of Sports and Culture of the Northern Cape Provincial Administration, Government Printer, Pretoria.

Republic of South Africa, 2017, Northern Cape Tourism Authority annual report Department of Economic Development and Tourism of the Northern Cape Provincial Administration, Government Printer, Pretoria.

Republic of South Africa, Auditor-General of South Africa, 2013, Public Finance Management Act (PFMA) General report, Government Printer, Pretoria.

Republic of South Africa, Auditor-General of South Africa, 2015, Public Finance Management Act (PFMA) General report, Government Printer, Pretoria.

Republic of South Africa, National Treasury, 2016, Budget speech, Government Printer Pretoria.

Republic of South Africa, Statistics South Africa, 2020, Second quarter report, Government Printer, Pretoria.

Samanta, I. \& Lamprakis, A., 2018, 'Modern leadership types and outcomes: The case of Greek public sector', Journal of Contemporary Management Issues 23(1), 173-191. https://doi.org/10.30924/mjcmi/2018.23.1.173

Saunders, M., Lewis, P. \& Thornhill, A., 2009, Research methods for business students, Pearson Education, Essex.

Schniederjans, M. \& Cao, Q., 2009, 'Alignment of operations strategy, information strategic orientation, and performance: An empirical study', International Journal of Production Research 47(10), 2535-2563. https://doi.org/10.1080/002075407 01673465

Seifzadeh, S.A.P., 2013, 'The role of corporate controls, size and corporate headquarters in the effect of corporate-level strategy and business-leve performance', $\mathrm{PhD}$ thesis, University of Western Ontario, Ontario.

Serfontein, K. \& Hough, J., 2011, 'Nature of the relationship between strategic leadership and organisational performance', South African Journal of Economic and Management Sciences 14(4), 393-406. https://doi.org/10.4102/sajems. v14i4.21

Shaari, Z.H., Areni, C., Grant, D. \& Miller, R., 2014, 'Effects of chief executive officer's leadership on primary stakeholder interests: Review', Global Business and Management Research: International Journal 6(3), 246-250.

Suleiman, S.M., Hamad, A.U. \& Sulaiman, M.B., 2017, 'Governance and management of State-Owned enterprises in Zanzibar: A proposed model for effective performance', Mediterranean Journal of Social Sciences 8(5), 159-169. https:// doi.org/10.2478/mjss-2018-0108

Sull, D., Homkes, R. \& Sull, C., 2015, 'Why strategy execution unravels and what to do about it: Spotlight on where strategy stumbles', Harvard Business Review 93(3), $57-66$. 
Thompson, A.A., Strickland, A.J. \& Gamble, J.E., 2010, Crafting and executing strategy The quest for competitive advantage, 17th edn., McGraw-Hill, New York, NY

Tshandu, P.V., 2018, Woes of the Zuma economy, Sunday Times, 2 February.

Van der Merwe, M.M. \& Nienaber, H., 2015, 'Factors hindering strategy implementation as perceived by top, middle and frontline managers in a South African electronic organisation', Journal of Global Business and Technology 11(2), 45-57.

Van Schalkwyk, R.D., Davis, A. \& Pellissier, R., 2013, 'The impact of leadership practices on service quality in private higher education in South Africa', Journal of on service quality in private higher educ
Contemporary Management $10223-238$.

Vermeeren, B., Kuipers, B. \& Steijn, B., 2014, 'Does leadership style make a difference? Linking HRM, job satisfaction and organisational performance', Review of Public Personnel Administration 34(2), 174-195. https://doi.org/10.1177/07343 $71 \times 13510853$

Volberda, H.W., Morgan, R.E., Reinmoeller, P., Hitt, M.A., Ireland, R.D. \& White, C., 2011, Strategic Management, Palgrave Macmillan, New York, NY.

Volberda, H.W., Morgan, R.E., Reinmoeller, P., Hitt, M.A., Ireland, R.D. \& Hoskisson R.E., 2011, Strategic management concepts and cases: Competitiveness and globalisation, 9th edn., South-Western Higher Education, Hampshire.
Wang, Z., Chen, X. \& Yu, M., 2017, 'Interactive effect of leader-member tie and network centrality on leadership effectiveness', Social Behaviour and Personality 45(7), 1197-1210. https://doi.org/10.2224/sbp.6351

Winston, B.E. \& Patterson, K., 2006, 'An integrative definition of leadership', International Journal of Leadership Studies 1(2), 6-66.

White, C., 2004, Strategic management, Palgrave Macmillan, New York, NY.

Yahaya, R. \& Ebrahim, F., 2016, 'Leadership styles and organisational commitment: Literature review', Journal of Management Development 35(2), 190-216. https:// doi.org/10.1108/JMD-01-2015-0004

Yukl, G., 2010, Leadership in organisations, Pearson, Upper Saddle River, NJ.

Zheng, W., Yang, B. \& Mclean, G.N., 2010, 'Linking organisational culture, structure, strategy and organisational effectiveness: Mediating role of knowledge management', Journal of Business Research 63(7), 763-771. https://doi. org/10.1016/j.jbusres.2009.06.005

Zuned, A.M.A., 2017, 'Effective business leadership styles: A case study of Harriet Green', Middle East Journal of Business 12(2), 10-19. https://doi.org/10.5742/ MEJB.2017.92943 